\title{
Correction to: Comment on "On the Difficulties and Pitfalls with the Analysis of Solid-State 13C NMR Spectra in Graphitic Materials"
}

\author{
Anastasia Vyalikh $^{1}$ (D) Alexander V. Okotrub ${ }^{2,3}$. Victor O. Koroteev ${ }^{2}$ (D) \\ Lyubov G. Bulusheva ${ }^{2,3}$ (D)
}

Published online: 3 August 2021

(c) Springer-Verlag GmbH Austria, part of Springer Nature 2021

\section{Correction to: Applied Magnetic Resonance (2021) 52:81-90 https://doi.org/10.1007/s00723-020-01215-z}

The article "Comment on "On the Difficulties and Pitfalls with the Analysis of Solid-State 13C NMR Spectra in Graphitic Materials"” written by Anastasia Vyalikh, Alexander V. Okotrub, Victor O. Koroteev, Lyubov G. Bulusheva was originally published online first without open access. After publication in volume 52, issue 1, pages (81-90), the author decided to opt for open choice and to make the article an open access publication. Therefore, the copyright of the article has been changed to The Author(s) 2020 and the article is forthwith distributed under the terms of the Creative Commons Attribution 4.0 International License, which permits use, sharing, adaptation, distribution and reproduction in any medium or format, as long as you give appropriate credit to the original author(s) and the source, provide a link to the Creative Commons licence, and indicate if changes were made. The images or other third party material in this article are included in the article's Creative Commons licence, unless indicated otherwise in a credit line to the material. If material is not included in the article's Creative Commons licence and your intended use is not permitted by statutory regulation or exceeds the permitted use, you will need to obtain permission directly from the copyright holder. To view a

The original article can be found online at https://doi.org/10.1007/s00723-020-01215-z.

Anastasia Vyalikh

avyalikh@gmail.com

1 Institut für Experimentelle Physik, Technische Universität Bergakademie Freiberg, Leipziger Str. 23, 09599 Freiberg, Germany

2 Nikolaev Institute of Inorganic Chemistry, SB RAS, 3 Acad. Lavrentiev Ave, 630090 Novosibirsk, Russia

3 Novosibirsk State University, 2 Pirogova Str., 630090 Novosibirsk, Russia 
copy of this licence, visit http://creativecommons.org/licenses/by/4.0. The original article has been corrected.

Publisher's Note Springer Nature remains neutral with regard to jurisdictional claims in published maps and institutional affiliations. 